\title{
Media Video Animasi Guna Meningkatkan Sikap Tanggung Jawab Pada Anak Usia Dini
}

\section{Desi Cahyani Irawan ${ }^{*}$, Ahmad Rafiq ${ }^{2}$, Fitria Budi Utami ${ }^{3}$}

1,2,3 Jurusan Program Studi Pendidikan Guru Pendidikan Anak Usia Dini, Universitas Panca Sakti, Bekasi, Indonesia

\section{AR T I C L E I N F O}

Article history:

Received 14 Mei 2021

Revised 15 Mei 2021

Accepted 27 Juli 2021

Available online 25 Agustus 2021

Kata Kunci:

Video Animasi, Tanggung Jawab Anak

\section{Keywords:}

Animated Video, Children's

Responsibility

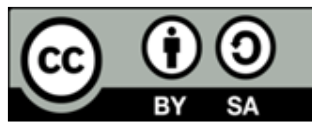

This is an open access article under the CC BY-SA license.

Copyright $(2021$ by Author. Published by Universitas Pendidikan Ganesha.

\begin{abstract}
A B S T R A K
Kurangnya sikap tanggung jawab anak disebabkan karena tontonan yang kurang baik dan kurang mendidik yang ditiru anak sehingga anak mudah meniru perilaku buruk. Penelitian ini bertujuan untuk menganalisis penggunaan media video animasi terhadap sikap tanggung jawab anak usia dini. Jenis penelitian ini menggunakan pendekatan penelitian kuantitatif dengan metode survey deskriptif. Sampel pada penelitian ini adalah 25 orang tua murid yang memiliki anak usia dini dan mendapatkan stimulasi media video animasi dari 3 guru di Sekolah. Pengumpulan data dilakukan dengan mengisi angket, melakukan observasi dan wawancara. Data dikumpulkan melalui tes yang telah divalidasi dengan analisis data menggunakan analisis statistik. Sebelum uji hipotesis dilakukan terlebih dahulu dilakukan uji normalitas dan uji homogenitas. Hasil analisis data menunjukkan bahwa terdapat hasil yang signifikan dalam proses pembelajaran media video animasi terhadap peningkatan sikap tanggung jawab anak usia dini, dengan hasil analisis Rhitung sebesar $=2,238>$ Rtabel $=2,238$ pada taraf signifikan $=0,05$. Berdasarkan hasil tersebut maka dapat disimpulkan bahwa media video animasi tentang tanggung jawab dapat digunakan dalam pembelajaran dan efektif untuk meningkatkan sikap tanggung jawab anak usia dini. Implikasi penelitian ini diharapkan agar dapat memahami dan memberikan pembelajaran yang tepat kepada anak agar perkembangan kemampuan sikap tanggung jawab anak dapat berkembang lebih baik lagi dan anak dapat dengan mudah menghadapi tantangan teknologi di level pendidikan selanjutnya.
\end{abstract}

\section{A B S T R A C T}

The lack of a child's attitude of responsibility is caused by a poor and uneducational spectacle that is imitated by children so that it is easy for children to imitate bad behavior. This study aims to analyze the use of animated video media on the responsible attitude of early childhood. This type of research uses a quantitative research approach with a descriptive survey method. The sample in this study were 25 parents of students who had early childhood and received animated video media stimulation from 3 teachers at the school. Data was collected by filling out questionnaires, conducting observations and interviews. Data collected through tests that have been validated by data analysis using statistical analysis. Before testing the hypothesis, the normality test and homogeneity test were carried out first. The results of data analysis showed that there were significant results in the learning process of animated video media on increasing the attitude of responsibility for early childhood, with the results of the analysis of Rcount $=2.238>$ Rtable $=2.238$ at a significant level $=0.05$. Based on these results, it can be concluded that the animated video media about responsibility can be used in learning and is effective in increasing the attitude of responsibility in early childhood. The implication of this research is that it is expected to be able to understand and provide appropriate learning to children so that the development of children's responsibility attitudes can develop better and children can easily face technological challenges at the next level of education.

\section{PENDAHULUAN}

Anak usia dini merupakan seorang individu unik dalam rentang usia nol sampai enam tahun yang sedang berada di masa keemasannya dimana pertumbuhan dan perkembangannya mengalami ledakan yang luar biasa pesat (Junanto \& Kusna, 2018; Maulidha \& Larasati, 2017). Pada masa ini proses pertumbuhan dan perkembangan dalam berbagai aspek sedang mengalami masa yang cepat dalam 
rentang perkembangan hidup manusia (Novitasari, 2018; Yuniarni, 2016). Salah satu perkembangan yang memiliki pengaruh besar dalam kehidupan sehari-hari anak adalah rasa tanggung jawab, karena tanggung jawab merupakan suatu karakter yang harus dimiliki oleh anak agar menjadi pribadi yang bertanggung jawab di masa yang akan datang dan kegagalan penanaman karakter akan menyebabkan masalah yang timbul di masa selanjutnya (Prasanti \& Fitrianti, 2018; Sutini, Halimah, \& Ismail, 2019). Aspek perkembangan sosial dan emosional adalah dua kata yang memiliki makna yang berbeda, tetapi sebenarnya aspek sosial emosional ini tidak dapat dipisahkan karena saling bersinggungan (Sufa \& Setiawan, 2018; Sutini et al., 2019). Perkembangan sosial emosional ini bertujuan agar terbentuknya karakter anak yang memiliki kepercayaan diri, kemampuan bersosialisasi, dan kemampuan mengendalikan emosi (Ramdhani, Yuliastri, Sari, \& Hasriah, 2019). Kemampuan dan pembentukan karakter anak tidaklah lahir begitu saja, ada proses yang dilewatinya sehingga proses tersebut menjadi karakter yang melekat dalam diri seorang anak (Prasanti \& Fitrianti, 2018). Pembelajaran karakter kepada anak usia dini tidak bisa instan, namun dalam pembelajaran bisa menanamkan nilai karakter yang menarik dan menyenangkan bagi anak seperti menggunakan media pembelajaran yang menyenangkan. Proses penerapan pembelajaran pendidikan karakter di PAUD menjadi pusat dan tema utama dalam dunia pendidikan di Indonesia (Ramdhani et al., 2019).

Namun, kenyataannya rendahnya sikap tanggung jawab anak menjadi topik hangat yang sering diperbincangkan baik di kalangan pendidik, orang tua maupun masyarakat. Kurangnya sikap tanggung jawab anak disebabkan karena tontonan yang kurang baik dan kurang mendidik yang ditiru anak sehingga anak mudah meniru perilaku buruk (Istova \& Hartati, 2016). Selain itu, Sikap tanggung jawab yang dimiliki anak usia 5-6 tahun belum muncul dalam sebagian besar anak dan sikap tanggung jawab yang belum muncul yaitu; mengerjakan tugas yang diberikan, meletakkan barang sesuai dengan tempatnya dan menghargai waktu (Ramdhani et al., 2019). Selain itu karakter tanggung jawab pada sebagian anak di TK belum berkembang secara optimal (Salsabila \& Tarigan, 2021). Ketidakmampuan anak usia dini mengenal sikap tanggung jawab sering ditujukkan melalui beberapa kasus seperti anak yang tidak tuntas mengerjakan tugas, tidak menjaga barang milik sendiri, tidak meminta maaf bila berbuat salah, anak yang tidak mau membereskan mainan dan peralatan yang sudah digunakan. Biasanya anak-anak meninggalkan begitu saja setelah bermain tanpa mau merapikan kembali, guru meminta anak untuk merapikan sendiri namun anak terlihat malas untuk merapikan mainan dan peralatan yang sudah digunakan (Ramdhani et al., 2019). Seharusnya proses penerapan pembelajaran pendidikan karakter di PAUD menjadi pusat dan tema utama dalam dunia pendidikan di Indonesia (Ramdhani et al., 2019), tetapi kebanyakan proses kegiatan pembelajaran di PAUD menekankan tentang aspek kognitif seperti kegiatan Calistung (Baca, Tulis, Hitung). Penekanan terhadap aspek kognitif di pembelajaran PAUD terutama di Taman Kanak-kanak menyebabkan aspek lainnya seperti aspek nilai agama dan moral, serta sosioemosional tidak bisa berjalan dengan baik apalagi dalam penerapan pembelajaran ditekankan tentang pendidikan karakter dan proses pembelajarannya tidak berjalan dengan baik. Padahal, sikap tanggung jawab dibentuk dari pendidikan karakter yang dimaknai sebagai upaya memunculkan potensi yang telah ada dalam diri masing-masing individu tetapi belum tergali. Jika permasalahan tersebut dibiarkan maka akan memberikan dampak buruk bagi pendidikan.

Solusi yang dapat ditawarkan untuk meningkatkan sikap tanggung jawab anak usia dini yaitu dengan menggunakan media pembelajaran berupa media video animasi dalam pembelajaran. Media pembelajaran akan membantu keefektifan proses pembelajaran dalam penyampaian pesan dan isi pelajaran. Media audio visual yaitu penggabungan antara media visual dengan media audio, media yang mempunyai unsur gambar dan unsur suara. Salah satu media audio visual adalah video pembelajaran (Syafi'i, Sa'diyah, Wakhidah, \& Umah, 2020). Kemampuan anak dalam mengingat kata-kata yang terdapat didalam dialog film tersebut akan mudah dan cepat diingat oleh anak. Apabila proses ini terus dilakukan oleh orang tua maupun pendidik kepada anak maka tanpa sadar anak menyimpan setiap kata-kata baru yang anak dengar, kemudian mereka mempraktekannya dengan teman- temannya, mereka mendapat kesenangan dengan hal tersebut, dan seiring berjalannya waktu, kosa kata anak semakin bertambah (Sutini et al., 2019). Media video animasi sewajarnya memiliki pesan-pesan yang positif yang disisipkan melalui adegan maupun dialog dalam film. Pendidik sebaiknya selektif dalam memilih tayangan yang pantas untuk dikonsumsi, terutama jika tayangan tersebut diperuntukkan untuk anak-anak, film animasi sebaiknya memiliki pesan positif seperti nilai moral, kebajikan, dan nilai positif lainnya, sehingga dampak yang dihasilkan dari menonton film animasi tersebut merupakan dampak yang positif. Salah satu nilai positif yang dapat disisipkan lewat sebuah film animasi adalah "tanggung jawab". Penggunaan media film animasi, narasi, dan teks sebagai cara untuk menyampaikan pesan-pesan pembelajaran (Ela Paramita, Hasmalena, 2017; Lukman, Hayati, \& Hakim, 2019). Penggabungan ketiga unsur tersebut ternyata mampu meningkatkan daya ingat siswa dan siswa dapat mengimplementasikan pengetahuannya. 
Dalam pembentukan sikap tanggung jawab pondasi pendidikan yang pertama bagi anak adalah keluarga dan sikap pendidik sangat membantu dalam mengembangkan potensi anak, di antaranya yakni menghargai opini anak serta mendorong anak untuk mengutarakannya, menyediakan kesempatan bagi anak-anak dalam melakukan perenungan, khayalan, berpikir, serta memperbolehkan anak dalam pengambilan keputusan secara individu dan memberi stimulus padanya agar senantiasa banyak bertanya, serta memberi penguatan pada anak dengan menghargai rasa ingin mencoba hal baru, menunjang dan mendorong kegiatan anak, menikmati keberadaannya bersama anak, memberi sanjungan yang sungguhsungguh kepada anak, mendorong kemandirian anak dalam bekerja dan menjalin hubungan kerja sama yang baik dengan anak (Cahyati, Syafdaningsih, \& Rukiyah, 2018; Lilawati, 2020). Tingkah laku dan ucapan yang dilakukan oleh orang tua akan ditiru dan dicontoh oleh anak-anak. begitu pula dengan kebiasaan ayah dan ibu dalam kegiatan literasi (Inten, 2017). Kegiatan balajar tidak ditekankan pada hasil tetapi pada proses belajar, jadi yang lebih utama adalah menyusun strategi bagaimana agar siswa memperoleh pengetahuan dengan cara mengalami bukan menghafal (Aijer, 2020; Wahono, Sa'ada, \& Kurniawati, 2017). Oleh karena itu agar anak bisa belajar menyenangkan tentunya pendidik sebagai fasilitator sebagai penunjang pembelajaran anak yang menarik, sehingga anak dapat mengikuti dan meniru perbuatan sesuai dengan harapan.

Temuan penelitian sebelumnya menyatakan media pembelajaran Digital Storytelling juga dapat meningkatkan hasil belajar siswa dan terbukti efektif menunjang proses pembelajaran siswa (Panjaitan, Yetti, \& Nurani, 2020). Hal yang menjadi daya tarik adalah penggunaan audio, visual maupun animasi yang memberikan pilihan belajar visual dan audio dibandingkan audio saja. Hasil-hasil penelitian tersebut merupakan acuan untuk memanfaatkan media video animasi dalam peningkatan sikap tanggung jawab bagi anak. Penggunaan buku bercerita dengan membaca langsung dari buku cerita dongeng maupun ilustrasi gambar untuk mengembangkan kemampuan sikap tanggung jawab anak berhasil dan sangat berpengaruh, namun sangat disayangkan keberadaan media elektronik dalam proses pembelajaran di PAUD juga memiliki peranan yang penting (Weni, 2018). Media video memberikan kemudahan bagi peserta didik untuk belajar yang menyenangkan (A. C. Dewi, 2018; Fitria, 2018; Lukman et al., 2019). Memanfaatkan teknologi di dunia pendidikan yang menjadikan proses pembelajaran terasa lebih menyenangkan (Agustika, 2020; N. L. P. A. Dewi, Jampel, \& Tegeh, 2017). Berdasarkan hal tersebut, penelitian ini bertujuan untuk menerapkan media video animasi untuk mengetahui peningkatan sikap tanggung jawab anak usia dini.

\section{METODE}

Pendekatan yang digunakan dalam penelitian ini merupakan pendekatan kuantitatif dengan metode penelitian survei deskriptif. Pengambilan data langsung kepada sumbernya dengan pengumpulan data seperti wawancara, angket, dan observasi yang akan dianalisis menggunakan skala likert. Sampel dalam penelitian yaitu 25 orang tua peserta didik dan 3 wali kelas Guru Sekolah Lebah Madu Cipayung Jakarta Timur. Objek penelitian sebanyak 25 anak usia dini.

Tabel 1. Kisi - Kisi Instrumen Penggunaan Media Video Animasi Guna Mengetahui Sikap Tanggung Jawab Anak Usia Dini

\begin{tabular}{lll}
\hline Materi & Indikator & Bulir Soal \\
\hline Keberanian & Meminta maaf jika melakukan kesalahan & 1,2 \\
Optimis & Menjaga barang milik sendiri dan orang lain & $3,4,5$ \\
Tanggung Jawab & Merapikan kembali barang pribadi dan orang lain & $6,7,8$ \\
& setelah digunakan & \\
\hline
\end{tabular}

Tabel 2. Kisi-kisi Peningkatan Sikap Tanggung Jawab Anak Usia Dini Terhadap Media Video Animasi

\begin{tabular}{llll}
\hline Aspek & Indikator & Bulir Soal \\
\hline Keberanian & Anak semakin berani dalam mengambil & 1,2 \\
& keputusan & \\
Optimis & Anak bertanggung jawab menyelesaikan tugas & $3,4,5$ \\
Tanggung Jawab & Anak semakin berempati merapikan dan & $6,7,8$ \\
& membantu orang lain & \\
\hline
\end{tabular}

Pengumpulan data dilakukan dalam bentuk kuesioner melalui Google form dengan menggunakan skala likert dengan rentang teoritik perolehan skor responden yang telah diolah menjadi skor nilai dengan rentang skor dari 1 sampai dengan 5 setelah data terkumpul selanjutnya dilakukan pengolahan data 
menggunakan teknik analisis yang digunakan untuk menganalisis data hasil penelitian dengan teknik analisis statistik deskriptif dan teknik analisis statistik inferensial dengan menentukan distribusi frekuensi, nilai rerata (mean), median, modus, simpangan baku, varians, dan menggambarkanya dalam bentuk tabel. Sedangkan untuk mengetahui pengaruh media video animasi terhadap peningkatan sikap tanggung jawab anak usia dini digunakan analisis untuk menguji hipotesis dengan uji validitas, uji normalitas, uji homogenitas.

\section{HASIL DAN PEMBAHASAN}

Hasil

Hasil peningkatan sikap tanggung jawab anak sebelum dilakukannya uji dengan menonton menggunakan media video animasi diperoleh hasil pengolahan data Variabel X didapatkan rata-rata 19, simpangan baku 3,452, nilai yang sering muncul 21, dengan nilai maksimum 25 dan minimum 8 . Sedangkan hasil peningkatan sikap tanggung jawab anak setelah dilakukannya uji dengan menonton menggunakan media video animasi diperoleh hasil pengolahan hasil pengolahan data Variabel Y didapatkan rata-rata 20,8, simpangan baku 3,873, nilai yang sering muncul 18, dengan nilai maksimum 28 dan minimum 10. Adapun kumpulan data analisis disajikan menggunakan rumus SPSS 20 dengan data sebagai berikut.

Tabel 3. Hasil Uji Validitas

\begin{tabular}{ccccccccc}
\hline R. $x * y$ & 0,7681 & 0,7619 & 0,7130 & 0,7313 & 0,6640 & 0,5480 & 0,7126 & 0,5170 \\
Rtabel & 0,4438 & & & & & & \\
Kesimpulan & VALID & VALID & VALID & VALID & VALID & VALID & VALID & VALID \\
Valid & 8 & & & & & & & \\
Invalid & 0 & & & & & & \\
\hline
\end{tabular}

Untuk memenuhi uji hipotesis, perlu dilakukan uji validitas yang menunjukkan valid atau tidaknya suatu kuisioner. Berdasarkan analisis dengan memasukkan rumus diperoleh seperti pada tabel didapatkan data valid, maka peneliti dapat melanjutkan kembali penelitian ini.

Tabel 4. Hasil Uji Normalitas (One-Sample Kolmogorov-Smirnov Test)

\begin{tabular}{cccc}
\hline Levene Statistic & & $\begin{array}{c}\text { Media Video } \\
\text { Animasi }\end{array}$ & Tanggung Jawab Anak \\
\hline $\mathrm{N}$ & Mean & 25 & 25 \\
Normal & 19,0000 & 20,8000 \\
Parameters & & $3, \mathrm{a}$ & \\
& Std. Deviation &, 15205 & 3,87298 \\
Most Extreme & Absolute &, 121 &, 155 \\
Differences & Positive &,- 159 &, 085 \\
& Negative &, 794 &,- 155 \\
Kolmogorov- & &, 554 &, 774 \\
Smirnov Z & &, 587 \\
Asymp. Sig. (2- & & & \\
tailed) & &
\end{tabular}

Hasil perhitungan uji normalitas pada data tersebut menunjukkan bahwa data pada penelitian berdistribusi normal. Nilai signifikasi 0,554 >0,05, maka dapat disimpulkan bahwa data berdistribusi normal. Hasil pengujian normalitas dan homogenitas dari data tersebut menunjukkan bahwa data pada penelitian ini berdistribusi normal dan memiliki varians data yang homogeny. Sesuai hasil analisis uji homogenitas menggunakan $\alpha 0,05$ sebagai taraf nyata, maka didapatkan 0,584 $>0,05$, dapat disimpulkan bahwa distribusi data homogen. 
Tabel 5. Hasil Perhitungan Uji Hipotesis

\begin{tabular}{ccc}
\hline & Variabel X & Variabel Y \\
& Media Film Animasi & Sikap Tanggung Jawab \\
\hline Rata-rata & 19 & 20,8 \\
Simpangan baku & 3,45205253 & 3,872983 \\
Varians & 11,91666667 & 15 \\
Dkk & $\mathrm{n} 1+\mathrm{n} 2-2$ & 48 \\
\hline
\end{tabular}

Berdasarkan analisis dengan memasukkan rumus diperoleh data, selisih rata-rata $-1,8$, varians $1 / n 10,476666667$, varians $2 / n 20,6,2$ koefisien korelasi 0,94741295 , simpangan baku/akar n10,690410506, simpanganbaku/akarn20,774596669. Dengan memasukkan rumus, maka didapatkan datat-hitung -2,38416 dan t-tabel 2,010635. Hasil penelitian membuktikan bahwa variabel independen (bebas), yaitu adanya media film animasi berpengaruh terhadap variabel dependen (terikat), yaitu sikap tanggung jawab anak usia dini sebesar $-2,010635<0,05$, ternyata hasilnya ditolak maka didapatlah $\mathrm{H} 1$ diterima. Sehingga dapat disimpulkan bahwa H1 diterima, bahwa adanya pengaruh H1 yang berbunyi "terdapat adanya pengaruh media film animasi terhadap peningkatan sikap tanggung jawab anak usia dini Di Sekolah Lebah Madu Cipayung Jakarta Timur".

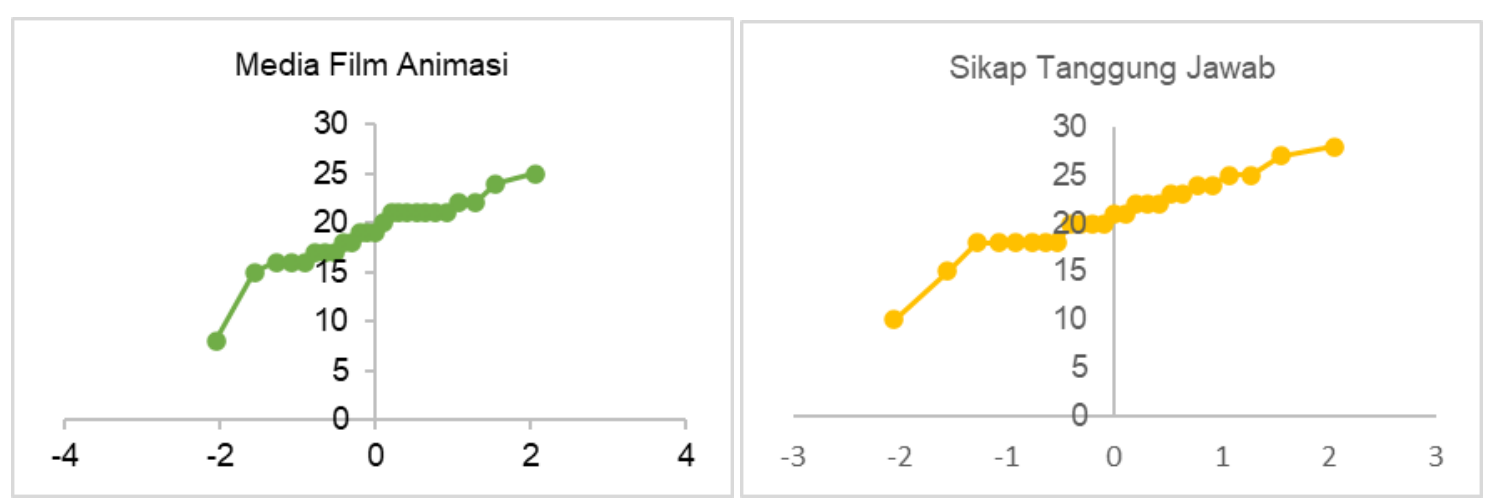

Gambar 1. Hasil Analisis Pengaruh Media Film Animasi Terhadap Peningkatan Sikap Tanggung Jawab Anak Usia Dini

Berdasarkan grafik pada tabel, peneliti dapatkan hasil berdasarkan perhitungan analisis dan pengumpulan data melalui google form, bahwa pembelajaran dengan menggunakan media film animasi memiliki pengaruh yang signifikan terhadap peningkatan sikap tanggung jawab anak usia dini. Adanya video animasi sebagai pembelajaran menunjang proses belajar. Media pembelajaran video animasi juga dapat meningkatkan hasil belajar siswa dan terbukti efektif menunjang proses pembelajaran siswa (F. F. Dewi \& Handayani, 2021; Lukman et al., 2019). Pelajaran yang dibuat visualisasi kedalam bentuk gambar animasi lebih bermakna dan menarik, lebih mudah diterima, dan dipahami anak. Hasil belajar siswa menggunakan pembelajaran kooperatif yang diintegrasikan dengan media animasi komputer lebih baik secara signifikan (Najib, 2016; Setiantono, 2012). Selain itu terdapat beberapa faktor yang menyebabkan terjadinya peningkatan karakter anak setelah diterapkannya media video animasi.

Pertama, media animasi pendidikan memudahkan anak didik memahami dan mengingat nilainilai karakter. Seperti diketahui karakter dibentuk melalui pembiasaan. Pembiasaan bermula dari pengetahuan. Pengetahuan yang baik dan terbiasa dilakukan akan membentuk karakter. Ada anak didik melakukan perbuatan baik karena sudah mengetahui perbuatan baik. Namun ada pula anak didik yang melakukan perbuatan tidak baik karena ia tidak mengetahui apa itu perbuatan baik. Pengetahuan tentang perbuatan baik atau sikap-sikap luhur atau karakter yang berbudi pekerti perlu kembali ditingkatkan. Salah satu caranya dengan menerapkan media audio visual berupa film animasi pendidikan. Media animasi pendidikan diterapkan saat pembelajaran untuk memberikan kepada siswa tentang pemahaman nilai-nilai karakter. Prosedur pemanfaatannya yaitu dipilih media animasi pendidikan yang mengandung konten karakter dan memiliki kaitan dengan materi atau tema pembelajaran yang sedang berlangsung di TK Lebah Madu. Pemutaran animasi pendidikan dilakukan pada kegiatan inti pembelajaran. Pemutaran animasi berdurasi 5-10 menit, setelah ditayangkan media animasi ternyata siswa lebih mudah memahami dan mengingat jenis-jenis sikap yang baik salah satunya sikap tanggung jawab. Penggunaan media audio visual mampu meningkatkan pemahaman dan daya ingat siswa terhadap materi (Isdayanti, 2020; Kristiana, 2020; Putri, Handayani, \& Akbar, 2020). 
Kedua, pemutaran media animasi yang berulang-ulang mendorong anak didik untuk meniru perilaku tokoh-tokoh baik dalam film animasi. Artinya dengan pembiasaan pemberian nilai-nilai membuat karakter baik anak mulai terbentuk. Berdasarkan hasil observasi dan wawancara kepada guru kelas dan orang tua siswa, ternyata setelah sekian hari pemutaran media film animasi ternyata ada beberapa anak menunjukkan sikap yang baik. Ada anak yang sebelumnya tidak peduli dengan kerapian, seperti mainan yang dibiarkan berantakan, setelah menyajikan media video animasi tentang tangggung jawab merapikan kembali mainan setelah digunakan, ternyata anak meniru perilaku tersebut. Ada juga anak yang mengalami peningkatan sikap tanggung jawab, sebelumnya ia tidak pernah tuntas mengerjakan tugas yang diberikan guru, namun setelah menonton animasi tentang tanggung jawab dan mengetahui akibat negatif dari melalaikan tanggung jawab, ia mulai mengerjakan tugas-tugas secara tuntas. Menanamkan karakter seseorang dimulai dari caranya berpikir. Untuk itu cara berpikir anak perlu diarahkan dan perlu pembiasaan untuk selalu berpikir tentang hal-hal yang baik, karena dengan berpikir yang baik anak akan berkata yang baik (Fadlullah, 2017; Pitaloka, Dimyati, \& Edi, 2021). Dengan berkata yang baik anak akan membentuk perbuatan yang baik. Perbuatan baik dan sering dilakukan akan membentuk kebiasaan. Kebiasaan yang baik akan membentuk karakter yang baik pula (Dozan \& Fitriani, 2020; Ramdhani et al., 2019).

Ketiga, sebagian orang tua setuju dengan memberikan tontonan media video animasi kepada anaknya karena dengan menonton membantu anaknya dalam meningkatkan motivasi belajar dan sikap baik. Ketika anak memanfaatkan penggunaan benda elektronik tentu harus adanya pengawasan oleh orang tua, orang tua memang sangat penting atau menjadi tombak perkembangan anaknya sendiri. Penggunaan video pembelajaran memiliki dampak kognitif dan afektif, yaitu dalam membangkitkan minat anak, memudahkan anak untuk berkonsentrasi, praktek pembelajaran yang lebih santai, mengembangkan imajinasi, mendukung kreativitas (Andriyani \& Suniasih, 2021; Wijayanti \& Fauziah, 2020). Dalam hal ini terdapat juga perbedaan yang signifikan antara anak yang belajar menggunakan model pembelajaran quantum menggunakan media film animasi dengan yang menggunakan media pembelajaran konvensional (Ginting, Putra, \& Negara, 2017). Penelitian ini menunjukan bagaimana cara anak berprilaku terhadap orang yang berada disekitarnya selain pondasi keluarga juga tergantung anak meniru video animasi yang dilihatnya. Penelitian ini memperoleh hasil memang benar adanya pengaruh yang positif antara variabel bebas dengan variabel terikatnya.

Temuan ini diperkuat dengan temuan sebelumnya yang menyatakan bahwa media video pembelajar efektif digunakan dalam proses pembelajaran (Luhulima, Degeng, \& Ulfa, 2017; Ponza, Jampel, \& Sudarma, 2018). Media video memberikan kemudahan bagi peserta didik untuk belajar yang menyenangkan (A. C. Dewi, 2018; Fitria, 2018; Lukman et al., 2019). Memanfaatkan teknologi di dunia pendidikan yang menjadikan proses pembelajaran terasa lebih menyenangkan (Agustika, 2020; N. L. P. A. Dewi et al., 2017). Meskipun dalam hasil-hasil penelitian yang telah dikumpulkan dan dianalisis menyatakan positif, bahwa adanya pengaruh media film animasi terhadap sikap tanggung jawab anak, namun kemajuan sistem pendidikan tersebut sebagai upaya yang dilakukan pada bidang pendidikan untuk meningkatkan kualitas pendidikan Indonesia, pada kenyataannya ketidaksiapan guru dalam menyampaikan materi yang sesuai cenderung membuat peserta didik menjadi salah dalam menyikapi kemajuan (Aisyah, 2018). Padahal, anak usia dini membutuhkan pembelajaran dan pemahaman yang tepat karena pada usia ini anak akan banyak mendengar dan meniru apa yang dilihatnya. Implikasi penelitian ini diharapkan agar dapat memahami dan memberikan pembelajaran yang tepat kepada anak agar perkembangan kemampuan sikap tanggung jawab anak dapat berkembang lebih baik lagi dan anak dapat dengan mudah menghadapi tantangan teknologi di level pendidikan selanjutnya. Adanya pengaruh media film animasi terhadap perkembangan sikap dan karakter anak usia dini sehingga peneliti lain juga dapat mengembangkan dengan melakukan penelitian tidak terbatas hanya pengaruh peningkatan sikap tanggung jawab anak saja, tetapi juga pada pengembangan motivasi diri, empati dan hubungan sosial atau pengembangan sikap lainnya.

\section{SIMPULAN}

Penggunaan media film animasi berpengaruh terhadap peningkatan sikap tanggung jawab anak usia dini, hal ini dapat dilihat dari beberapa anak yang sebelumnya tidak peduli dengan kerapian, seperti mainan yang dibiarkan berantakan, setelah guru menyajikan film animasi anak mulai merapikan kembali mainan yang telah digunakan dan anak yang sebelumnya tidak pernah tuntas mengerjakan tugas yang diberikan guru, setelah menonton film animasi tentang tanggung jawab anak mulai mengerjakan tugastugas secara tuntas.S elain itu pendampingan orang tua dan pendidik tergantung bagaimana cara mengaplikasikan dan mengontrol penggunaannya kepada anak agar dapat menghasilkan sesuatu yang baik bagi perkembangannya baik di dunia pendidikan maupun di kehidupan sehari-harinya. 


\section{DAFTAR RUJUKAN}

Agustika, N. L. G. M. W. G. N. S. (2020). Intensitas Penggunaan Gadget Oleh Anak Usia Dini. Jurnal Pendidikan Anak Usia Dini, 8(2), 112-120. https://doi.org/10.23887/paud.v8i2.25179.

Aijer, R. N.-. (2020). Meningkatkan Kemampuan Mengenal Lambang Bilangan Melalui Penggunaan Balok Angka Pada Anak Usia 5-6 Tahun Di Taman Kanak. Journal-Uim-Makassar.Ac.Id, 8(1), 170-179. Retrieved from http://journal-uim-makassar.ac.id/index.php/AIJER/article/view/311.

Aisyah, E. N. (2018). Internalisasi Nilai Karakter Nasionalisme melalui Dongeng dan Tari (DORI) bagi Anak Usia Dini. Golden Age: Jurnal Pendidikan Anak Usia Dini, 2(2), 26-34. https://doi.org/10.29313/ga.v2i2.4293.

Andriyani, N. L., \& Suniasih, N. W. (2021). Development Of Learning Videos Based On Problem-Solving Characteristics Of Animals And Their Habitats Contain in Science Subjects On 6th-Grade. Journal of Education, 5(1), 37-47. https://doi.org/10.23887/jet.v5i1.32314.

Cahyati, N., Syafdaningsih, S., \& Rukiyah, R. (2018). Pengembangan Media Interaktif Dalam Pengenalan Kata Bermakna Pada Anak. Cakrawala Dini: Jurnal Pendidikan Anak Usia Dini, 9(2), 160-170. https://doi.org/10.17509/cd.v9i2.11339.

Dewi, A. C. (2018). Pengaruh Model Pembelajaran Inquiry Berbantuan Media Animasi Terhadap Kompetensi Pengetahuan Ipa. Journal for Lesson and Learning Studies, 1(3), 154-161. https://doi.org/10.23887/jlls.v1i3.15371.

Dewi, F. F., \& Handayani, S. L. (2021). Pengembangan Media Pembelajaran Video Animasi En-Alter Sources Berbasis Aplikasi Powtoon Materi Sumber Energi Alternatif Sekolah Dasar. Jurnal Basicedu, 5(4), 2530-2540. https://doi.org/10.31004/basicedu.v5i4.1229.

Dewi, N. L. P. A., Jampel, I. N., \& Tegeh, I. M. (2017). Microsoft Power Point Terhadap Kemampuan Mengenal Lambang Bilangan Pada Anak. E-Journal Pendidikan Anak Usia Dini Universitas Pendidikan Ganesha, 5(1), 33-44. https://doi.org/10.23887/paud.v8i3.25070.

Dozan, W., \& Fitriani, L. (2020). Membangun Karakter Anak Usia Dini Melalui Nilai-Nilai Islam Dalam Tradisi Perang Timbung. Murhum. Jurnal Pendidikan Anak Usia Dini, 1(1), 1-15. https://doi.org/10.37985/murhum.v1i1.2.

Ela Paramita, Hasmalena, S. (2017). Pengembangan Dongeng Berbentuk Video Animasi Untuk Ank Usia 56 Tahun di TK Negeri Pembina 2 Palembang. Tumbuh Kembang: Kajian Teori Dan Pembelajaran PAUD, 6(1), 49-58. https://doi.org/10.36706/jtk.v6i1.8350.

Fadlullah. (2017). Pendidikan Anak Usia Dini dalam Perspektif Islam. Ta Dib : Jurnal Pendidikan Islam, 6(2), 308-320. https://doi.org/10.29313/tjpi.v6i2.3195.

Fitria, A. (2018). Penggunaan Media Audio Visual Dalam Pembelajaran Anak Usia Dini. Cakrawala Dini: Jurnal Pendidikan Anak Usia Dini, 5(2), 57-62. https://doi.org/10.17509/cd.v5i2.10498.

Ginting, T. B., Putra, I. K. A., \& Negara, I. G. A. O. (2017). Pengaruh Penerapan Model Pembelajaran Quantum Menggunakan Media Film Animasi Terhadap Perkembangan Kemampuan Kosakata Pada Anak Kelompok B. Jurnal Pendidikan Anak Usia Dini Universitas Pendidikan Ganesha, 5(1), 110. https://doi.org/10.23887/paud.v5i1.11558.

Inten, D. N. (2017). Peran Keluarga dalam Menanamkan Literasi Dini pada Anak. Golden Age: Jurnal Pendidikan Anak Usia Dini, 1(1), 23-32. https://doi.org/10.29313/ga.v1i1.2689.

Isdayanti, D. (2020). Pengembangan Media Pembelajaran Audio Visual Berbasis Adobe Flash Pada Materi Daur Hidup Hewan. JIPP (Jurnal Ilmiah Pendidikan Dan Pembelajaran, 4(2), 390-406. https://doi.org/10.23887/jipp.v4i2.27320.

Istova, M., \& Hartati, T. (2016). Pengaruh Media Film Animasi Fiksi Islami Untuk Meningkatkan Kemampuan Menyimak dan Berbicara Siswa Sekolah Dasar. Jurnal Universitas Pendidikan Indonesia, 2(1), 72-86. https://doi.org/10.30870/jpsd.v2i1.669.

Junanto, S., \& Kusna, N. A. A. (2018). Evaluasi Program Pembelajaran di PAUD Inklusi dengan Model

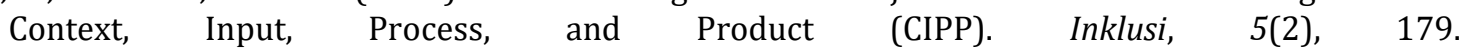
https://doi.org/10.14421/ijds.050202.

Kristiana, A. A. I. D. (2020). Meningkatkan Keterampilan Berbicara Siswa Melalui Model Pembelajaran Role Playing Berbantuan Media Audio Visual. Jurnal Mimbar Ilmu, 25(3), 449-459. https://doi.org/10.23887/mi.v25i3.26388.

Lilawati, A. (2020). Peran Orang Tua dalam Mendukung Kegiatan Pembelajaran di Rumah pada Masa Pandemi. Jurnal Obsesi: Jurnal Pendidikan Anak Usia Dini, 5(1), 549. https://doi.org/10.31004/obsesi.v5i1.630.

Luhulima, D., Degeng, I. N., \& Ulfa, S. (2017). Pengembangan Video Pembelajaran Karakter Mengampuni Berbasis Animasi untuk Anak Sekolah Minggu. Jurnal Inovasi Dan Teknologi Pembelajaran, 3(2), 110-120. https://doi.org/10.17977/um031v3i22017p110.

Lukman, A., Hayati, D. K., \& Hakim, N. (2019). Pengembangan Video Animasi Berbasis Kearifan Lokal pada 
Pembelajaran IPA Kelas V di Sekolah Dasar. Elementary: Jurnal Ilmiah Pendidikan Dasar, 5(2), 153. https://doi.org/10.32332/elementary.v5i2.1750.

Maulidha, M., \& Larasati, D. (2017). Faktor-Faktor yang Mempengaruhi Keterlambatan Perkembangan Anak Usia 1-3 Tahun di Desa Cangkringsari Kecamatan Sukodono Kabupeten Sidoarjo. Journal of Issues In Midwifery, 1(1), 51-70. https://doi.org/10.21776/ub.joim.2017.001.01.6.

Najib, D. A. dan E. (2016). Pengaruh Penerapan Pembelajaran Bermakna (Meaningfull Learning) Pada Pembelajaran Tematik IPS Terpadu Terhadap Hasil Belajar Siswa Kelas III di MI Ahliyah IV Palembang. Jurnal PGMI, 2(1), 19-28. Retrieved from. http://jurnal.radenfatah.ac.id/index.php/jip/article/view/1063.

Novitasari, Y. (2018). Analisis Permasalahan "Perkembangan Kognitif Anak Usia Dini". PAUD Lectura: $\begin{array}{lllll}\text { Jurnal Pendidikan Anak } & \text { 82-90. }\end{array}$ https://doi.org/10.31849/paudlectura.v2i01.2007.

Panjaitan, N. Q., Yetti, E., \& Nurani, Y. (2020). Pengaruh Media Pembelajaran Digital Animasi dan Kepercayaan Diri terhadap Hasil Belajar Pendidikan Agama Islam Anak. Jurnal Obsesi : Jurnal Pendidikan Anak Usia Dini, 4(2), 588. https://doi.org/10.31004/obsesi.v4i2.404.

Pitaloka, D. L., Dimyati, D., \& Edi, P. (2021). Peran Guru dalam Menanamkan Nilai Toleransi pada Anak Usia Dini di Indonesia. Jurnal Obsesi: Jurnal Pendidikan Anak Usia Dini, 5(2), 1696-1705. https://doi.org/10.31004/obsesi.v5i2.972.

Ponza, P. J. R., Jampel, I. N., \& Sudarma, I. K. (2018). Pengembangan Media Video Animasi pada Pembelajaran Siswa Kelas IV di Sekolah Dasar. Jurnal Edutech Undiksha, 6(1), 9-19. https://doi.org/10.23887/jeu.v6i1.20257.

Prasanti, D., \& Fitrianti, D. R. (2018). Pembentukan Karakter Anak Usia Dini: Keluarga, Sekolah, Dan Komunitas. Jurnal Obsesi: Jurnal Pendidikan Anak Usia Dini, 2(1), 13-19. https://doi.org/10.31004/obsesi.v2i1.2.

Putri, D. K., Handayani, M., \& Akbar, Z. (2020). Pengaruh Media Pembelajaran dan Motivasi Diri terhadap Keterlibatan Orang Tua dalam Pendidikan Anak. Jurnal Obsesi : Jurnal Pendidikan Anak Usia Dini, 4(2), 649. https://doi.org/10.31004/obsesi.v4i2.418.

Ramdhani, S., Yuliastri, N. A., Sari, S. D., \& Hasriah, S. (2019). Penanaman Nilai-Nilai Karakter melalui Kegiatan Storytelling dengan Menggunakan Cerita Rakyat Sasak pada Anak Usia Dini. Jurnal Obsesi : Jurnal Pendidikan Anak Usia Dini, 3(1), 153. https://doi.org/10.31004/obsesi.v3i1.108.

Salsabila, J., \& Tarigan, N. (2021). Studi Tentang Sikap Tanggung Jawab Anak Usia 5-6 Tahun Di TK Fajar Cemerlang Sei Mencirim. Jurnal Golden Age, 5(1), 111-118. https://doi.org/10.29408/goldenage.v5i01.3334.

Setiantono, T. (2012). Penggunaan Metode Bercerita Bagi Anak Usia Dini Di PAUD Smart Little Cilame Indah Bandung. Jurnal EMPOWERMENT, 1(2), 18-23. https://doi.org/10.22460/empowerment.v1i2p18-23.611.

Sufa, F. F., \& Setiawan, M. H. (2018). Optimalisasi Peran Orangtua Dalam Mengembangkan Potensi PAUD. ADIWIDYA, 2(2), 289-298. https://doi.org/10.33061/awpm.v2i2.2521.

Sutini, A., Halimah, L., \& Ismail, M. H. (2019). Model Pendidikan Karakter Berbasis Literacy Gardens Di Paud. Cakrawala Dini: Jurnal Pendidikan Anak Usia Dini, 10(1), 11-18. https://doi.org/10.17509/cd.v10i1.14457.

Syafi'i, I., Sa'diyah, C., Wakhidah, E. W., \& Umah, F. M. (2020). Penerapan Video Pembelajaran Daring Anak Usia Dini Pada Masa Pandemi Covid-19. Al-Athfaal: Jurnal Ilmiah Pendidikan Anak Usia Dini, 3(2), 140-160. https://doi.org/10.24042/ajipaud.v3i2.7315.

Wahono, Sa'ada, N., \& Kurniawati, T. (2017). Pembelajaran Interaktif Media Film Pendek. Pedagogi : Jurnal Anak Usia Dini Dan Pendidikan Anak Usia Dini, 3(3), 198-211. Retrieved from https://core.ac.uk/download/pdf/229569990.pdf.

Weni, R. P. (2018). Peningkatan Kemampuan Mengenal Lambang Bilangan Melalui Metode Proyek Dengan Media Kartu Pintar Siswa TK Pertiwi Banteran Kecamatan Wangon Kabupaten Banyumas. AsSibyan: Jurnal Pendidikan Anak Usia Dini, 2(2), 147-163. Retrieved from. http://jurnal.uinbanten.ac.id/index.php/assibyan/article/view/1363.

Wijayanti, R. M., \& Fauziah, P. Y. (2020). Perspektif dan Peran Orangtua dalam Program PJJ Masa Pandemi Covid-19 di PAUD. Jurnal Obsesi: Jurnal Pendidikan Anak Usia Dini, 5(2), 1304-1312. https://doi.org/10.31004/obsesi.v5i2.768.

Yuniarni, D. (2016). Peran Paud Dalam Mengoptimalkan Tumbuh Kembang Anak Usia Dini Demi Membangun Masa Depan Bangsa. Jurnal Visi Ilmu Pendidikan, 8(1), 1-13. https://doi.org/10.26418/jvip.v8i1.27370. 